\title{
PENGARUH STRUKTUR PENGENDALIAN INTERNAL, KUALITAS SUMBER DAYA MANUSIA, KELENGKAPAN DOKUMEN ARSIP USAHA DAN FUNGSI MANAJEMEN TERHADAP PERKEMBANGAN USAHA MIKRO KECIL DAN MENENGAH (UMKM) DI KABUPATEN BANYUMAS
}

\author{
EFFECT OF INTERNAL CONTROL STRUCTURE, QUALITY OF HUMAN RESOURCES, \\ COMPLETENESS OF BUSINESS RECORDS DOCUMENTS AND MANAGEMENT \\ FUNCTIONS OF THE DEVELOPMENT OF MICRO, SMALL AND MEDIUM \\ ENTERPRISES (MSMES) IN BANYUMAS REGENCY
}

\author{
Rini Widianingsih*), Icuk Rangga Bawono*), Rasyid Mei Mustafa *), Isman Setyo \\ Nugroho **) \\ *Akuntansi Fakultas Ekonomi dan Bisnis, Universitas Jenderal Soedirman \\ **Arsiparis Universitas Jenderal Soedirman \\ Korespondensi : ri3n.wibowo@gmail.com \\ Diterima: 4 Juni 2019, Direvisi: 26 Juni 2019, Disetujui: 10 Juli 2019
}

\begin{abstract}
ABSTRAK
Penelitian ini merupakan penelitian studi empiris dengan survei pada UMKM di Kabupaten Banyumas. Tujuan dari penelitian ini adalah untuk mengetahui kondisi struktur pengendalian intern UMKM, mengetahui perkembangan UMKM di Kabupaten Banyumas, mengetahui signifikansi pengaruh struktur pengendalian intern, kualitas sumber daya manusia, kelengkapan dokumen arsip usaha UMKM dan fungsi manajemen terhadap perkembangan usaha UMKM baik secara simultan maupun parsial dan untuk mengetahui variabel yang paling berpengaruh terhadap perkembangan usaha UMKM. Penelitian ini menggunakan analisis regresi berganda. Berdasarkan hasil penelitian diperoleh kesimpulan bahwa struktur pengendalian intern pada UMKM di Kabupaten Banyumas telah memadai. Terdapat perkembangan usaha UMKM di Kabupaten Banyumas dari tahun 2012 sampai dengan tahun 2016. Secara simultan struktur pengendalian intern, kualitas sumber daya manusia, kelengkapan dokumen arsip usaha dan fungsi manajemen berpengaruh signifikan terhadap perkembangan usaha UMKM di Kabupaten Banyumas. Secara parsial kualitas sumber daya manusia dan kelengkapan dokumen arsip usaha berpengaruh signifikan terhadap perkembangan usaha UMKM di Kabupaten Banyumas, sedangkan struktur pengendalian intern dan fungsi manajemen tidak berpengaruh terhadap perkembangan usaha UMKM di Kabupaten Banyumas. Kualitas Sumber Daya Manusia merupakan variabel yang paling berpengaruh terhadap perkembangan usaha UMKM di Kabupaten Banyumas.
\end{abstract}

Kata Kunci : Perkembangan Usaha UMKM, Struktur Pengendalian Intern, Kualitas Sumber Daya Manusia, Dokumen Arsip Usaha dan Fungsi Manajemen

\section{ASBTRACT}

This research is an empirical study with a survey of MSMEs in Banyumas Regency. The purpose of this study was to determine the condition of the structure of internal control of MSMEs, to know the development of MSMEs in Banyumas Regency, to know the significance of the influence of internal control structures, the quality of human resources, the completeness of MSME business records and management functions on the development of MSME businesses both simultaneously and partially. to find out the variables that most influence the business development of MSMEs. This study uses multiple regression analysis. Based on the results of the study, it was concluded that the 
structure of internal control in MSMEs in Banyumas District was adequate. There are developments in the business of MSMEs in Banyumas Regency from 2012 to 2016. Simultaneously the structure of internal control, quality of human resources, completeness of business records and management functions have a significant effect on the development of MSME businesses in Banyumas Regency. Partially the quality of human resources and completeness of business records documents have a significant effect on the development of MSME businesses in Banyumas Regency, while the internal control structure and management functions have no effect on the development of MSME businesses in Banyumas Regency. Quality of Human Resources is the most influential variable on the development of MSME business in Banyumas Regency.

Keywords: MSME Business Development, Internal Control Structure, Quality of Human Resources, Business Archive Documents and Management Functions

\section{PENDAHULUAN}

Usaha Mikro, Kecil, dan Menengah (UMKM) merupakan bagian penting dalam kehidupan perekonomian suatu negara dan memberikan kontribusi dalam meningkatkan kesejahteraan masyarakat, khususnya di negara-negara berkembang yang jumlah penduduknya padat, termasuk Indonesia. UMKM menyediakan kesempatan kerja dan pendapatan yang cukup besar bagi masyarakat sehingga dapat mengurangi salah satu permasalahan yang dihadapi Indonesia yaitu pengangguran. Selain memberikan pendapatan bagi masyarakat, UMKM juga dapat meningkatkan ekspor Indonesia. Saat ini kontribusi UMKM terhadap perekonomian Indonesia telah melebihi separuh dari PDB. Data dari Badan Pusat Statistik (BPS) menunjukkan pada tahun 2009 komposisi PDB nasional tersusun dari UKM sebesar 53,32\%, kemudian usaha besar 41,00\%, dan sektor pemerintah $5,68 \%$. Meski memiliki peran yang sangat penting, mengembangkan UMKM bukanlah suatu hal yang mudah dilakukan. Dalam prosesnya, beberapa dari UMKM ada yang dapat berkembang dan kemudian mencapai keberhasilan dari tahun ke tahun, namun tak sedikit yang mengalami kegagalan dan bahkan harus menutup usahanya (Kristiningsih dan Trimarjono, 2014).
Dilihat dari definisinya, ada beberapa lembaga dan regulasi yang bisa menjadi rujukan. Kementrian Negara Koperasi dan Usaha Kecil Menengah (Menegkop dan UKM), Badan Pusat Statistik (BPS), Keputusan Menteri Keuangan No 316/KMK.016/1994 tanggal 27 Juni 1994, dan UU No. 20 Tahun 2008. Definisi UKM memberikan definisi berbeda-beda antara satu dengan yang lainnya. Menurut Kementrian Menteri Negara Koperasi dan Usaha Kecil Menengah (Menegkop dan UKM), bahwa yang dimaksud dengan Usaha Kecil (UK), termasuk Usaha Mikro (UMI), adalah entitas usaha yang mempunyai memiliki kekayaan bersih paling banyak Rp 200.000.000, tidak termasuk tanah dan bangunan tempat usaha, dan memiliki penjualan tahunan paling banyak $\mathrm{Rp}$ 1.000.000.000. Sementara itu, Usaha Menengah (UM) merupakan entitas usaha milik warga negara Indonesia yang memiliki kekayaan bersih lebih besar dari Rp 200.000.000 s.d. Rp 10.000.000.000, tidak termasuk tanah dan bangunan.

Adapun istilah perkembangan usaha UMKM dapat dirunut dari arti kata perkembangan yang dalam arti harfiah adalah bertambah besar/bertambah sempurna, sedangkan usaha adalah kegiatan atau aktivitas agar diperoleh hasil lebih baik (Winardi, 1992). Jadi perkembangan usaha adalah suatu kegiatan dengan 
mengerahkan tenaga dan pikiran agar mendapat perubahan yang lebih baik atau bertambah maju, baik dari segi kualitatif maupun kuantitatif sesuai dengan tujuan yang sudah ditetapkan. Perkembangan Potensi Usaha Mikro, Kecil dan Menengah (UMKM) di Indonesia tidak terlepas dari dukungan perbankan dalam penyaluran kredit kepada UMKM. Kontribusi Usaha Mikro Kecil dan menengah terhadap produk domestik bruto meningkat dari 57,84\% menjadi $60,34 \%$ dalam 5 tahun terakhir. Serapan tenaga kerja pada sektor ini juga meningkat dari $96,99 \%$ menjadi $97,22 \%$ pada periode yang sama.

Beberapa hal yang memiliki pengaruh penting terhadap perkembangan UMKM adalah pengendalian internal dan sumber daya manusianya. Pelaksanaan pengendalian intern akan selalu berhubungan dengan sumber daya manusia (Ompusunggu, 2002).

Pada awalnya perkembangan istilah struktur pengendalian intern dimulai dari internal cek yang kemudian berkembang menjadi struktur pengendalian intern. Sebelumnya istilah yang dipakai untuk pengendalian inern adalah sistem pengendalian intern, sistem pengawasan intern dan struktur pengendalian intern. Mulai tahun 2001 istilah resmi yang digunakan IAI adalah pengendalian intern. Menurut Mulyadi (2001) pengendalian intern meliputi struktur organisasi, metode dan ukuran-ukuran yang dikoordinasikan untuk menjaga kekayaan organisasi, mengecek ketelitian dan keandalan data akuntansi, mendorong efisiensi dan mendorong dipatuhinya kebijakan manajemen.

Untuk menyediakan suatu struktur dalam mempertimbangkan banyak kemungkinan pengendalian yang berhubungan dengan tujuan entitas, terdapat lima komponen pengendalian intern yang saling berhubungan yaitu (Laporan
COSO dan AU 319.07 dalam Boynton, 2001):a) lingkungan pengendalian (control environment); b) penilaian resiko (risk assessment); c) nformasi dan komunikasi; d) aktivitas pengendalian; e) pemantauan (Monitoring).

Tujuan SPI menurut Mulyadi (2001) adalah: a) menjaga kelayakan organisasi; b) mengecek ketelitian dan keandalan data akuntansi; c) mendorong efisiensi; d) mendorong dipatuhinya kebijakan manajemen.

Dari aspek Sumber Daya Manusia, Nogi dalam Jesus (2006) dalam Izzaty (2011) menyatakan bahwa kualitas SDM adalah unsur yang sangat penting dalam meningkatkan pelayanan organisasi terhadap kebutuhan publik. Oleh karena itu, terdapat dua elemen mendasar yang berkaitan dengan pengembangan SDM yaitu tingkat pendidikan dan keterampilan yang dimiliki karyawan/pekerja. Frekuensi pelatihan yang diselenggarakan pemerintah ataupun swasta dapat meningkatkan kualitas sumberdaya manusia selain dari sisi pendidikan formal.

Untuk kelengkapan dokumen arsip usaha, terdapat beberapa jenis, yaitu dokumen, arsip, dan perizinan. Dokumen perusahaan/organisasi adalah data, catatan dan/ atau keterangan yang dibuat dan/atau diterima oleh perusahaan/organisasi dalam rangka pelaksanaan kegiatannya, baik tertulis di atas kertas atau sarana lain, maupun terekam dalam bentuk corak apapun yang dapat dilihat, dibaca, dan didengar (Undang-Undang Nomor 8 tahun 1991 pasal 1).

Menurut Gie (1990:1) arsip adlah kumpulan warkat yang disimpan secara sistematis karena mempunyai kegunaan agar setiap kali diperlukan dapat secara tepat diketemukan. Jenis Arsip menurut Wursanto (1991:21) : a) arsip keuangan; b) arsip kepegawaian; c) arsip pemasaran, dan d) arsip pendidikan. 
Perizinan merupakan legalitas kepada seorang atau pelaku usaha/kegiatan tertentu, baik dalam bentuk izin maupun tanda daftar usaha (Yuridika :1993). Secara Umum tujuan dan fungsi perizinan adalah untuk pengendalian dari aktivitasaktivitas pemerintah terkait ketentuanketentuan yang berisi pedoman yang harus dilaksanakan baik oleh yang berkepentingan ataupun oleh pejabat yang diberi kewenangan. Kelengkapan Izin Usaha yang diperlukan menurut centrausaha.com ada berbagai macam kelengkapan dokumen yang harus dipenuhi ketika mendirikan usaha baik itu dalam bentuk $\mathrm{CV}$, Firma. Atau PT yang dalam hal ini digunakan untuk legalitas usaha. Dokumen atau surat ini nantinya akan dikeluarkan oleh instansi terkait. Ada 12 macam jenis dokumen yang terkait perizinan usaha yaitu: 1) Surat Keterangan Domisili Usaha; 2) Nomor Pokok Wajib Pajak (NPWP); 3) Izin Usaha Dagang; 4) Surat Izin Tempat Usaha; 5) Surat Izin Prinsip; 6) Surat Izin Usaha Industri; 7) Surat Izin usaha Perdagangan; 8) Tanda Daftar perusahaan; 9) Tanda Daftar Industri; 10) HO Surat Izingangguan; 11) Surat izin Mendirikan Bangunan (IMB); 12) Izin BPOM.

Masalah utama pengembangan UMKM yaitu mengenai pengelolaan keuangan dalam usahanya tersebut, karena pengelolaan yang baik memerlukan keterampilan akuntansi yang baik pula oleh pelaku bisnis UMKM. Hampir semua UMKM tidak memiliki laporan kinerja usaha dan keuangan yang baik. Hal ini terjadi karena UMKM tidak dibiasakan untuk melakukan pencatatan dan penyusunan laporan keuangan sebagai gambaran kegiatan usaha dan posisi keuangan perusahaan. Padahal dengan adanya laporan keuangan akan memungkinkan pemilik memperoleh data dan informasi yang tersusun secara sistematis.
Untuk kelengkapan arsip dokumen usaha sudah mulai harus ditertibakan sejak berdirinya UMKM tersebut. Dokumen tersebut terdiri dari dokumen pendirian atau akta pendirian, surat TDP dan Surat Ijin Usaha yang sekarang menjadi Ijin Usaha Mikro Kecil. Dokumen tersebut yang kadang kurang diperhatikan oleh pelaku UMKM sehingga banyak UMKM di Kabupaten Banyumas yang masih belum terdaftar resmi di data Dinas Tenaga Kerja, Koperasi dan UMKM Kabupaten Banyumas.

$$
\text { Menurut Terry }
$$
"Manajemen adalah suatu proses tertentu yang terdiri dari perencanaan, pengorganisasian, pelaksanaan dan pengawasan penggunaan suatu ilmu dan seni yang bersama-sama menyelesaikan tugas untuk mencapai tujuan.”. Jadi Fungsi Manajemen adalah bagaimana proses dalam manajemen tersebut sudah dilaksanakan dengan baik dan benar di UMKM.

Urgensi keberhasilan usaha pada UMKM yang telah dipaparkan diatas membuat ketertarikan penulis untuk melakukan penelitian pada faktor-faktor yang mempengaruhi perkembangan usaha pada UMKM di kabupaten Banyumas.

Berdasarkan penjelasan di atas, dapat dirumuskan permasalahan sebagai berikut; 1) apakah struktur pengendalian intern, kualitas sumber daya manusia, kelengkapan dokumen arsip usaha dan fungsi manajemen secara simultan berpengaruh terhadap perkembangan usaha UMKM; b) apakah struktur pengendalian intern,kualitas sumber daya manusia, kelengkapan dokumen arsip usaha, dan fungsi manajemen secara parsial berpengaruh terhadap perkembangan usaha; serta c) manakah faktor yang paling berpengaruh terhadap perkembangan usaha UMKM. Dengan demikian, tujuan dari penelitian ini adalah: 1) Untuk mengetahui secara simultan 
pengaruh struktur pengendalian intern, kualitas sumber daya manusia, kelengkapan dokumen arsip usaha dan fungsi manajemen terhadap perkembangan usaha UMKM di Kabupaten Banyumas; 2) Untuk mengetahui secara parsial pengaruh struktur pengendalian intern, kualitas sumber daya manusia, kelengkapan dokumen arsip usaha, dan fungsi manajemen terhadap perkembangan usaha UMKM di Kabupaten Banyumas, dan 3) Untuk mengetahui faktor manakah yang paling berpengaruh terhadap perkembangan usaha UMKM di Kabupaten Banyumas.

Penelitian ini diharapkan dapat memberikan gambaran tentang faktorfaktor yang mempengaruhi perkembangan usaha UMKM di Kabupaten Banyumas, khususnya untuk era sekarang ini. Perkembangan digital, sistem informasi, ketrampilan pelaku UMKM, fungsi manajerial dan Undang-undang tentang UMKM menjadi tolak ukur dimana UMKM itu bisa berkembang dengan cepat di suatu daerah. Pemerintah selalu memberikan kebijakan terhadap tebentuknya suatu usaha kecil, mikro, dan menengah dengan kelengkapan dokumen arsip usaha mereka supaya terdapat pemerataan terhadap bantuan dari pemerintah. Selain itu penelitian ini diharapkan dapat memberikan manfaat sumbangsih bagi perkembangan ilmu pengetahuan dan sebagai bahan informasi serta dapat digunakan sebagai referensi dalam penelitian selanjutnya. Sebagai sumbangsih pemikiran bagi pihak-pihak yang ingin mendirikan UMKM, maupun bagi UMKM yang sedang tumbuh dan berkembang.

Terkait dengan perumusan masalah dan tujuan tersebut, maka dapat dirumuskan hipotesis penelitian sebagai beriktu:

1) Pengaruh secara simultan Struktur pengendalian intern, kualitas sumber daya manusia, kelengkapan dokumen arsip usaha dan fungsi manajemen terhadap perkembangan usaha UMKM di Kabupaten Banyumas.

Pelaksanaan pengendalian intern akan selalu berhubungan dengan sumber daya manusia (Ompusunggu, 2002). Dalam pelaksanaannya, pengendalian intern membutuhkan kualitas sumber daya manusia yang memadai. Oleh karena itu, kualitas sumber daya manusia pada suatu entitas sangat dipertimbangkan. Menurut Soedirman (2006) dalam UMKM Indo (2010) pada umumnya para pengurus dan manajer UMKM dikelola oleh tim manajemen dengan status pendidikan yang tidak begitu tinggi, sehingga kemampuan manajerialnya juga kurang memadai. Apalagi pelatihan sebagai media penambah wawasan dan kemampuan manajerial Bagi pelaku UMKM belum tersedia secara optimal. Sementara Dodge dan John, Xeeli dan Allan, (1999) dan Barbara, et al (2000), mengatakan bahwa permasalahan bidang pemasaran, keuangan, dan manajemen sangat berpengaruh terhadap pengembangan UMKM.

$H 1$ : Struktur pengendalian intern, kualitas sumber daya manusia, kelengkapan dokumen arsip usaha dan fungsi manajemen secara simultan berpengaruh terhadap perkembangan usaha UMKM di Kabupaten Banyumas.

2) Pengaruh secara simultan Struktur pengendalian intern, kualitas sumber daya manusia, kelengkapan dokumen arsip usaha dan fungsi manajemen terhadap perkembangan usaha UMKM di Kabupaten Banyumas.

H2 : Struktur pengendalian intern,kualitas sumber daya manusia, kelengkapan dokumen arsip usaha, dan 
fungsi manajemen secara parsial berpengaruh terhadap perkembangan usaha UMKM di Kabupaten Banyumas.

3) Variabel yang paling berengaruh terhadap perkembangan UMKM di Kabupaten Banyumas.

Nogi dalam Jesus (2006) dalam Izzaty (2011) menyatakan bahwa kualitas SDM adalah unsur yang sangat penting dalam meningkatkan pelayanan organisasi terhadap kebutuhan publik. Oleh karena itu, terdapat dua elemen mendasar yang berkaitan dengan pengembangan SDM yaitu tingkat pendidikan dan keterampilan yang dimiliki karyawan/pekerja. Frekuensi pelatihan yang diselenggarakan pemerintah ataupun swasta dapat meningkatkan kualitas sumberdaya manusia selain dari sisi pendidikan formal. Menurut Daeli, dkk (2006) faktor yang menentukan keberhasilan dalam mengelola UMKM adalah pendidikan formal. Sedangkan Notoadmodjo dalam Izzaty (2011) menyatakan bahwa kualitas SDM menyangkut dua aspek, yaitu aspek kualitas fisik dan aspek kualitas nonfisik, yang menyangkut kemampuan bekerja, berpikir, dan keterampilanketerampilan lain. Sumber daya manusia (SDM) berkualitas tinggi adalah SDM yang mampu menciptakan bukan saja nilai komparatif, tetapi juga nilai kompetitif-generatif-inovatif dengan menggunakan energi tertinggi seperti intelligence, creativity, dan imagination; tidak lagi semata-mata menggunakan energi kasar seperti bahan mentah, lahan, air, tenaga otot, dan sebagainya (Ndraha,1997 dalam Izzaty, 2011).

H3 : Kualitas Sumber daya manusis adalah variabel yang paling berpengaruh terhadap perkembangan usaha UMKM di Kabupaten Banyumas.

\section{METODE PENELITIAN}

Penelitian ini adalah penelitian deskriptif kuantitatif dengan metode survey menggunakan kuesioner dengan tujuan mencari informasi langsung dari pihak yang bersangkutan. Pihak yang bersangkutan adalah Pelaku Usaha UMKM di Kabupaten Banyumas. Peneliitan ini dilaksanakan mulai bulan Maret 2018 sampai dengan bulan Agustus 2018.

Instrumen dalam peneltian ini adalah pengendalian inernal, kualitas sumber daya manusia, kelengkapan dokumen arsip usaha, fungsi manajemen dan perkembangan usaha UMKM. Populasi dalam penelitian ini adalah UMKM yang sudah terdaftar di Dinas Tenaga Kerja, Koperasi dan UMKM Kabupaten Banyumas. Metode yang digunakan dalam pengambilan sampel adalah dengan purposive sampling dengan tujuan untuk mendapatkan sampel yang representative sesuai dengan kriteria yang ditentukan. Kriteria pengambilan sampel dalam penelitian ini adalah:

1) UMKM yang sudah memiliki Surat Izin usaha Mikro kecil.

2) UMKM yang sudah menjalankan usaha minimal 2 tahun.

3) UMKM yang Memiliki hasil penjualan tahunan kurang dari Rp300.000.000,00 (tiga ratus juta rupiah).

Teknik statistik yang digunakan untuk menguji hipotesis yang diajukan dalam penelitian ini adalah dengan menggunakan regresi linier berganda. Persamaan umumnya adalah:

$\mathrm{Y}=\alpha+\mathrm{b}_{1} \mathrm{X}_{1}+\mathrm{b}_{2} \mathrm{X}_{2}+\mathrm{b}_{3} \mathrm{X}_{3}+\mathrm{b}_{4} \mathrm{X}_{4+} \mathrm{e}$

Keterangan :

$\mathrm{Y}=$ Perkembangan usaha UMKM

$\alpha=$ Konstanta

$b_{1}=$ Koefisien regresi variabel struktur pengendalian intern

$\mathrm{b}_{2}=$ Koefisien regresi variable kualitas sumber daya manusia 


$$
\begin{aligned}
\mathrm{b}_{3}= & \text { Koefisien regresi variabel } \\
& \text { kelengkapan dokumen arsip usaha } \\
\mathrm{b}_{4}= & \text { Koefisien regresi variabel fungsi } \\
& \text { manajemen } \\
\mathrm{X}_{1}= & \text { struktur pengendalian intern } \\
\mathrm{X}_{2}= & \text { kualitas Sumber daya manusia } \\
\mathrm{X}_{3}= & \text { kelengkapan dokumen arsip usaha } \\
\mathrm{X}_{4}= & \text { fungsi manajemen } \\
\mathrm{e}= & \text { error }
\end{aligned}
$$

\section{HASIL DAN PEMBAHASAN \\ Gambaran Umum Responden}

$$
\text { Jumlah dari UMKM di }
$$

Kabupaten Banyumas tahun terahir

berdasarkan data yang sudah terdaftar di Dinas Tenaga Kerja, Koperasi dan UMKM sebanyak 66.530 unit dan jumlah tenaga kerja 100.729. Jumlah UMKM terbesar pada sektor perdagangan hotel dan restauran yaitu sebesar 36.014 atau $54,26 \%$, pertanian, peternakan, kehutanan dan perikanan sebesar 11.621 atau $17,47 \%$, dan industri pengolahan sebesar
10.394 atau $15,62 \%$. Metode yang digunakan dalam pengambilan sampel adalah dengan purposive sampling dengan tujuan untuk mendapatkan sampel yang representative sesuai dengan kriteria yang ditentukan. Kriteria pengambilan sampel dalam penelitian ini adalah:

a) UMKM yang sudah memiliki Surat Izin usaha Mikro kecil.

b) UMKM yang sudah menjalankan usaha minimal 2 tahun.

c) UMKM yang Memiliki hasil penjualan tahunan kurang dari Rp.300.000.000,00 (tiga ratus juta rupiah).

Jumlah Sampel yang dihasilkan sebanyak 250 UMKM. Kuesioner yang disebar sebanyak 250 lembar, kepada pelaku UMKM yaitu manajer/pemilik usaha. Jumlah yang kembali 180 lembar, sisanya tidak kembali dikarenakan rusak dan tidak diisi.

Tabel 1.

Deskripsi Umum Responden

\begin{tabular}{llcc}
\hline No & \multicolumn{1}{c}{ Keterangan } & Jumlah & Persentase \\
\hline 1. & Jenis Kelamin & & \\
& Laki-laki & 105 & $58,33 \%$ \\
& Perempuan & 75 & $41,67 \%$ \\
\hline 2. & Umur Responden & & \\
& $\leq 30$ tahun & 19 & $10,5 \%$ \\
& 31-40 tahun & 65 & $36,1 \%$ \\
& 41-50 tahun & 58 & $32,2 \%$ \\
& 251 tahun & 38 & $21,2 \%$ \\
\hline 3. & Lama Usaha & & \\
& <2 tahun & 0 & \\
& 2-5 tahun & 150 & $83,3 \%$ \\
& $>5$ tahun & 30 & $16,7 \%$ \\
\hline
\end{tabular}

\section{Analisis Deskriptif}

a) Struktur Pengendalian Internal

Pelaksanaan struktur pengen-

dalian intern pada UMKM di
Kabupaten Banyumas dijabarkan sebagai berikut: 
Tabel 2.

Struktur Pengendalian Internal Pada UMKM di Kabupaten Banyumas

\begin{tabular}{|c|c|c|c|c|c|c|c|c|c|c|c|}
\hline \multirow[t]{2}{*}{ No } & \multirow[t]{2}{*}{ Keterangan } & \multicolumn{2}{|c|}{$\begin{array}{l}\text { Lingkungan } \\
\text { Pengendalian }\end{array}$} & \multicolumn{2}{|c|}{$\begin{array}{l}\text { Penilaian } \\
\text { Resiko }\end{array}$} & \multicolumn{2}{|c|}{$\begin{array}{c}\text { Informasi dan } \\
\text { Komunikasi }\end{array}$} & \multicolumn{2}{|c|}{ Aktivitas } & \multicolumn{2}{|c|}{ Pemantauan } \\
\hline & & (f) & $(\%)$ & (f) & $(\%)$ & (f) & $(\%)$ & (f) & $(\%)$ & (f) & $(\%)$ \\
\hline 1 & Sangat tidak memadai & - & - & - & - & - & - & - & - & - & - \\
\hline 2 & Tidak memadai & 10 & 5,5 & - & - & - & - & - & - & - & - \\
\hline 3 & Cukup memadai & 75 & 41,6 & 125 & 69,4 & 85 & 47,2 & 80 & 44,4 & 130 & 72,2 \\
\hline 4 & Memadai & 50 & 27,8 & 40 & 22,2 & 50 & 27,8 & 70 & 38,9 & 30 & 16,7 \\
\hline 5 & Sangat memadai & 45 & 25 & 15 & 8,4 & 45 & 25 & 30 & 16,7 & 20 & 11,1 \\
\hline & Jumlah & 180 & 100 & 180 & 100 & 180 & 100 & 180 & 100 & 180 & 100 \\
\hline
\end{tabular}

Sumber: Data primer diolah, 2018

Tabel 2 menjelaskan bahwa sebagian besar responden menjawab telah menerapkan pengendalian internal walaupun masih cukup memadai dalam aktivitas usahanya. Dari kelima komponen pengendalian internal tersebut hanya lingkungan pegendalian yang terdapat jawaban responden tidak memadai. Dengan demikian, dapat disimpulkan bahwa lingkungan pengendalian, penilaian risiko, informasi dan komunikasi, aktivitas, pengendalian dan pemantauan sudah sebagian besar diterapkan oleh UMKM di Kabupaten Banyumas.

\section{b) Kualitas Sumber Daya Manusia}

Kualitas sumber daya manusia dalam penelitian ini diukur dengan indikator pendidikan dan pengalaman bekerja. Kondisi kualitas sumber daya manusia pada UMKM di Kabupaten Banyumas adalah sebagai berikut:

Tabel 3.

Kualitas Sumber Daya Manusia Pada UMKM di Kabupaten Banyumas.

\begin{tabular}{llcc}
\hline No & Keterangan & Frekuensi (f) & Persentase $(\%)$ \\
\hline 1 & Sangat tidak memadai & 5 & 2,8 \\
2 & Tidak memadai & 100 & 55,5 \\
3 & Cukup memadai & 50 & 27,8 \\
4 & Memadai & 15 & 8,3 \\
5 & Sangat memadai & 10 & 5,6 \\
\hline & TOTAL & 180 & 100 \\
\hline
\end{tabular}

Sumber : Data Primer Diolah 2018

Tabel 3 menjelaskan bahwa kualitas sumber daya manusia pada UMKM di Kabupaten Banyumas sebagian besar tidak memadai yaitu sebanyak 100 UMKM dan ada 5 UMKM yang tidak memadai. Hal tersebut dikarenakan sebagian UMKM adalah usaha mikro kecil maka pemilik usaha sama dengan manajer dan juga merangkap sebagai karyawan sehingga tidak memperhatikan tingkat pendidikan dan pengalaman dalam bekerja.

\section{c) Kelengkapan Dokumen Arsip Usaha}

Variabel kelengkapan dokumen arsip usaha dalam penelitian ini diukur menggunakan instrumen pernyataan yang berhubungan dengan dokumen apa saja yang sudah dimiliki oleh UMKM di Kabupaten Banyumas. Untuk usaha mikro kecil dokumen yang dimiliki yaitu mencakup; IUMK, Surat Keterangan Usaha dari Desa, Surat Keterangan domisili usaha dan NPWP. Pengukuran 
indikator digunakan skala pengukuran dengan skala likert 1 sampai 5. Setiap jawaban yang diperoleh dari responden dideskripsikan dengan kriteria sebagai berikut:

Tabel 4

Kelengkapan Dokumen Arsip Usaha Pada UMKM di Kabupaten Banyumas.

\begin{tabular}{llcc}
\hline No & \multicolumn{1}{c}{ Keterangan } & Frekuensi (f) & Persentase (\%) \\
\hline 1 & Tidak Lengkap & 80 & 44,4 \\
2 & Kurang Lengkap & 50 & 27,7 \\
3 & Sedang & 30 & 16,7 \\
4 & Lengkap & 10 & 5,6 \\
5 & Sangat Lengkap & 10 & 5,6 \\
\hline \multicolumn{2}{l}{ TOTAL } & 180 & 100 \\
\hline
\end{tabular}

Sumber : Data Primer Diolah 2018

Tabel 4 menjelaskan bahwa sebagian besar UMKM di Kabupaten Banyumas arsip dokumen usahanya tidak lengkap yaitu ada 80 UMKM. Sebagian besar UMKM karena masih usaha mikro kecil jadi hanya memiliki Surat Ijin Usaha dari desa atau IUMK dari Dinas Tenaga Kerja, Kopersi dan UMKM. Sebagian besar belum memiliki surat domisili usaha dan NPWP.

\section{d) Fungsi Manajemen}

Variabel fungsi manajemen dalam penelitian ini diukur menggunakan instrumen pernyataan dengan indikator fungsi manajemen menurut G.R Terry (1977). Untuk mengetahui fungsi manajemen UMKM di Kabupaten Banyumas digunakan skala pengukuran dengan skala likert 1 sampai 5

Tabel 5

Fungsi manajemen pada UMKM di Kabupaten Banyumas.

\begin{tabular}{llcc}
\hline No & \multicolumn{1}{c}{ Keterangan } & Frekuensi (f) & Persentase $(\%)$ \\
\hline 1 & Sangat tidak memadai & 25 & 13,8 \\
2 & Tidak memadai & 90 & 50 \\
3 & Cukup memadai & 50 & 27,8 \\
4 & Memadai & 15 & 8,3 \\
5 & Sangat memadai & - & - \\
\hline & TOTAL & 180 & 100 \\
\hline
\end{tabular}

Sumber : Data Primer Diolah 2018

Tabel 5 menjelaskan bahwa sebagian besar fungsi manajemen pada UMKM di Kabupaten Banyumas tidak memadai. Fungsi manajemen tersebut yaitu planning, organising, actuating, dan contolling. Sebanyak 90 UMKM tidak menerapkan fungsi manajemn secara sempurna hanya organising saja, dan 25 UMKM sama sekali tidak menerapkan fungsi manajemen. Hal tersebut dikarenakan berkaitan dengan variabel sumber daya manusia bahwa usaha mereka adalah milik sendiri jadi pemilik merangkap manajer dan karyawan.

\section{e) Perkembangan Usaha}

Perkembangan usaha UMKM dalam penelitian ini diukur dari angka indeks 
omzet usaha UMKM dari tahun 2012 sampai dengan tahun 2016. Omzet usaha adalah merupakan hasil perolehan dari aktivitas usaha yang dilakukan oleh
UMKM selama satu periode. Setiap ratarata perkembangan usaha dari tahun 2012 sampai dengan tahun 2016.

Tabel 6

Hasil Kriteria perkembangan usaha dalam 5 tahun terahir

\begin{tabular}{|c|c|c|c|}
\hline No & Rentang Persentae & Frekuensi (f) & Persentase (\%) \\
\hline 1 & $1 \%$ & 70 & 38,9 \\
\hline 2 & $20 \%$ & 60 & 33,3 \\
\hline 3 & $50 \%$ & 50 & 27,8 \\
\hline 4 & $75 \%$ & - & - \\
\hline 5 & $101 \%$ & - & - \\
\hline \multicolumn{2}{|c|}{ TOTAL } & 180 & 100 \\
\hline
\end{tabular}

Sumber : Data Primer Diolah 2018

Tabel 6 menjelaskan bahwa perkembangan usaha berdasarkan perhitungan kriteria perkembangan usaha pada UMKM di Kabupaten Banyumas dari tahun 2012 sampai dengan 2016 ada sebanyak 70 UMKM hanya memiliki kenaikan sebesar $1 \%$ saja, sedangkan 60 UMKM memiliki kenaikan sebesar 20\% kemudian ada 50 UMKM memiliki kenaikan sebesar 50\%. Dari perhitungan kenaikan perkembangan usaha sebagian besar kenaikannya sangat kecil, hal tersebut dikarenakan kualitas sumber daya manusia dan tidak berjalannya fungsi manajemen.

\section{Analisis Data}

Metode untuk uji validitas menggunakan metode korelasi product moment dangan bantuan software SPSS 17 for windows. Instrumen dinyatakan valid apabila nilai korelasi $r$ hitung lebih besar dari r tabel (Priyatno, 2002). Dari hasil uji validitas terhadap item pertanyaan struktur pengendalian intern, kualitas sumber daya manusia, kelengkapan dokumen usaha dan fungsi manajemen terbukti bahwa $r$ hitung lebih besar dari $r$ tabel $(0,355)$ sehingga keseluruhan item pertanyaan tersebut dikatakan valid (Lihat lampiran 5).

Reliabilitas menunjukkan konsistensi alat ukur dalam mengukur gejala yang sama. Metode yang digunakan untuk mengukur reliabilitasnya adalah teknik Cronbach Alpha. Koefisien reliabilitas diketahui dari besarnya koefisien alpha. Kriteria reliabiltas dikatakan reliabel bila koefisien alpha lebih besar dari 0,6. Sebaliknya apabila koefisien alpha lebih kecil atau kurang dari 0,6 maka menunjukkan tidak adanya konsistensi jawaban responden (Ghozali, 2005).

Uji normalitas dilakukan untuk mengetahui apakah sebaran residu regresi antar variabel terikat dan variabel bebas terdistribusi normal atau tidak. Pada penelitian ini uji normalitas data menggunakan metode Kolmogorof-Smirnov (Suliyanto, 2011). Nilai residual terstandarisasi secara normal jika $\mathrm{K}$ hitung < K tabel atau nilai Sig. $>$ alphanya $(\alpha=0,05)$. Hasil uji normalitas ditampilkan pada tabel 14. Berdasarkan tabel 14 dapat diketahui bahwa nilai signifikansi uji normalitas lebih besar dari nilai alphanya yaitu 0,05 , sehingga dapat 
diartikan data penelitian dalam penelitian ini terdistribusi normal.

Uji multikolinieritas merupakan uji yang bertujuan untuk menguji apakah model regresi terdapat korelasi antar variabel bebas (independen). Pengujian multikolinieritas dilakukan dengan prosedur SPSS yaitu dengan melihat hasil collinearity statistics khususnya dalam kolom VIF dan nilai tolerance. Jika nilai VIF kurang dari 10 dan tolerance lebih dari 0,1 maka model regresi bebas dari multikolinearitas (Priyatno, 2011). Hasil dari uji multikolinieritas adalah sebagai berikut:

Tabel 7

Hasil Uji Multikolinieritas

\begin{tabular}{|llcc|}
\hline Model & & \multicolumn{2}{c|}{ Collinearity Statistics } \\
1 & (Constant) & Tolerance & VIF \\
& SPI &, 919 & 1,088 \\
& Kualitas SDM &, 876 & 1,142 \\
& Kelengkapan Dokumen &, 864 & 1,157 \\
& Fungsi Manajemen &, 873 & 1,145 \\
\hline
\end{tabular}

Sumber: Data primer yang diolah

Dari hasil analisis multikolinieritas pada tabel 7 dapat dilihat bahwa variabel struktur pengendalian intern, kualitas SDM, kelengkapan dokumen dan fungsi manajemen nilai VIF-nya kurang dari 10 dan tolerance lebih dari 0,1 . Sehingga dapat disimpulkan bahwa keseluruhan variabel bebas (independent) tersebut tidak memiliki korelasi sehingga tidak terjadi multikolinieritas.

Nilai signifikansi untuk variabel struktur pengendalian intern, kualitas SDM, peranan pemerintah dan fungsi manajemen lebih dari nilai alpha 0,05 (sig. $>\alpha$ ), maka dapat dipastikan model tidak mengandung gejala heteroskedastisitas atau tidak terjadi heteroskedastisitas.

Untuk mengetahui pengaruh struktur pengendalian intern, kualitas sumber daya manusia, peranan pemerintah dan fungsi manajemen terhadap perkembangan usaha koperasi simpan pinjam dan unit simpan pinjam di Kabupaten Banyumas digunakan analisis regresi linier berganda. Perhitungan regresi linier berganda dilakukan dengan program SPSS 17 for Windows. Hasil perhitungan regresi linear berganda adalah sebagai berikut:

Tabel 8

Hasil Estimasi Regresi Linier Berganda

\begin{tabular}{llccc}
\hline No & \multicolumn{1}{c}{ Variabel } & Koefisien & T test & T tabel \\
\hline 1 & SPI & 0,002 & 0,100 & 2,056 \\
2 & Kualitas SDM & 0,110 & 3,574 & 2,056 \\
3 & Peranan Pemerintah & 0,174 & 3,483 & 2,056 \\
4 & Fungsi Manajemen & 0,092 & 0,935 & 2,056 \\
\hline & Koefisien determinasi $\left(\mathrm{R}^{2}\right)$ & $=0,558$ & & \\
& Konstanta & $=5,500$ & & \\
& F hitung & $=10,486$ & & \\
& F tabel & $=2,975$ & & \\
\hline
\end{tabular}

Sumber: Data primer diolah 
Dari tabel 8 tersebut dapat dibuat persamaan regresi sebagai berikut:

$Y=-5,500+0,002 X_{1}+0,110 X_{2}+0,174 X_{3}+$ $0,092 X_{4}+e$

Dari persamaan regresi dapat diartikan sebagai berikut:

1) Konstanta bernilai $-5,500$ artinya variabel dependen perkembangan usaha akan bernilai $-5,500$ apabila variabel independen yang terdiri atas pengaruh struktur pengendalian intern, kualitas sumber daya manusia, peranan pemerintah dan fungsi manajemen bernilai nol.

2) Koefisien variabel struktur pengendalian intern menunjukkan nilai positif yaitu sebesar 0,002. Hal tersebut menunjukan bahwa apabila variabel struktur pengendalian intern meningkat satu satuan, maka perkembangan usaha akan mengalami peningkatan sebesar 0,002 satuan dengan asumsi variabel independen lainnya bernilai tetap.

3) Koefisien variabel kualitas sumber daya manusia menunjukkan nilai positif yaitu sebesar 0,110 . Hal tersebut berarti bahwa apabila variabel kualitas sumber daya manusia meningkat satu satuan, maka perkembangan usaha akan mengalami peningkatan sebesar 0,110 satuan dengan asumsi variabel independen lainnya bernilai tetap.

4) Koefisien variabel peranan pemerintah menunjukkan nilai positif yaitu sebesar 0,174. Hal tersebut menunjukkan bahwa apabila variabel peranan pemerintah meningkat satu satuan, maka perkembangan usaha akan mengalami peningkatan sebesar 0,174 satuan dengan asumsi variabel independen lainnya bernilai tetap.

5) Koefisien variabel fungsi manajemen menunjukkan nilai positif yaitu sebesar 0,092. Hal tersebut berarti bahwa apabila variabel fungsi manajemen meningkat satu satuan, maka perkembangan usaha akan mengalami peningkatan sebesar 0,092 satuan dengan asumsi variabel independen lainnya bernilai tetap.

6) Dari persamaan regresi di atas perolehan koefisien determinasi $\left(\mathrm{R}^{2}\right)$ sebesar 0,558 atau 55,8 persen. Hal ini berarti variasi variabel perkembangan usaha dapat dijelaskan oleh variable struktur pengendalian intern, kualitas sumber daya manusia, peranan pemerintah dan fungsi manajemen sebesar 55,8 persen, sedangkan 44,2 persen dipengaruhi variabel lain yang tidak diteliti.

\section{Pembahasan}

Berdasarkan rekapitulasi perhitungan penerapan struktur pengendalian intern pada UMKM di Kabupaten Banyumas dalam keadaan memadai. Hasil penelitian ini sejalan dengan penelitian Istiqomah (2007) yang meneliti tentang pengendalian intern pada Koperasi Pegawai Republik Indonesia (KPRI) di Kabupaten Banyumas. Dalam penelitiannya tersebut menghasilkan bahwa pengendalian intern pada UMKM di Kabupaten Banyumas telah memadai. Rata-rata perkembangan usaha 185 UMKM di Kabupaten Banyumas tahun 2007-2011 mencapai 20,99\%. Hal tersebut berarti bahwa secara keseluruhan perkembangan usaha selama tahun 2007 sampai dengan tahun 2011 mengalami peningkatan sebesar $20,96 \%$.

Hasil penelitian secara simultan menunjukkan bahwa struktur pengendalian intern, kualitas sumber daya manusia, peranan pemerintah dan fungsi manajemen secara bersama-sama berpengaruh terhadap perkembangan usaha UMKM di Kabupaten Banyumas. Hasil 
penelitian ini membuktikan bahwa UMKM mengalami perkembangan usaha tidak didapat dengan cara yang instant, namun terdapat faktor pendukung di dalamnya.

Hasil penelitian menyebutkan bahwa variabel struktur pengendalian intern tidak berpengaruh signifikan terhadap perkembangan usaha UMKM di Kabupaten Banyumas. Hasil penelitian ini sejalan dengan penelitian yang dilakukan oleh Istiqomah (2007) yang menyatakan bahwa sistem pengendalian intern tidak berpengaruh signifikan terhadap perolehan UKM.

Dari hasil pengujian menunjukkan bahwa variabel kualitas sumber daya manusia berpengaruh signifikan terhadap perkembangan usaha UMKM. Penelitian ini sejalan dengan penelitian Rantau (1993) dan penelitian Daeli, dkk (2006) yang menyatakan bahwa faktor yang menentukan keberhasilan dalam mengelola UMKM adalah dari kualitas sumber daya manusia yang dilihat dari pendidikan formal, pengalaman pengurus dan pengalaman menduduki jabatan. Penelitian ini juga sejalan dengan hasil penelitian Antara dan Komenaung (2004) yang menyatakan bahwa sumber daya manusia berpengaruh signifikan terhadap kinerja keuangan maupun non keuangan pada UMKM.

Dalam hasil penelitian ini menunjukkan bahwa variabel peranan pemerintah berpengaruh signifikan terhadap perkembangan usaha UMKM di Kabupaten Banyumas. Hasil penelitian ini sejalan dengan penelitian yang dilakukan oleh Daeli, dkk (2006) yang menyatakan bahwa peranan pemerintah terbukti berpengaruh signifikan terhadap perkembangan UMKM. Hasil ini membuktikan bahwa program dan bantuan pemerintah sangat mendukung terhadap keberhasilan UMKM di Kabupaten Banyumas.
Hasil penelitian menunjukkan bahwa variabel fungsi manajemen tidak berpengaruh signifikan terhadap perkembangan UMKM di Kabupaten Banyumas. Hasil ini sejalan dengan hasil penelitian Antara dan Komenaung (2004) yang menyatakan dalam penelitiannya bahwa fungsi manajemen tidak berpengaruh terhadap UMKM, pelayanan dan assets. Walaupun fungsi manajemen UMKM telah terselenggara dengan baik namun akibat dari semakin bersaingnya lembaga keuangan mikro di Kabupaten Banyumas, maka tidak diikuti pula dengan kenaikan perkembangan usaha.

Dari keempat variabel independen yang diujikan, variabel peranan pemerintah merupakan variabel yang paling berpengaruh terhadap perkembangan usaha UMKM di Kabupaten Banyumas. Hal ini mengindikasikan bahwa campur tangan pemerintah masih sangat terasa dalam membantu perkembangan usaha koperasi di Kabupaten Banyumas khususnya pada UMKM di Kabupaten Banyumas.

\section{KESIMPULAN}

1. Struktur pengendalian intern, kualitas sumber daya manusia, kelengkapan dokumen arsip usaha dan fungsi manajemen secara simultan berpengaruh terhadap perkembangan usaha UMKM di Kabupaten Banyumas.

2. Struktur pengendalian intern, kualitas sumber daya manusia, kelengkapan dokumen arsip usaha, dan fungsi manajemen secara parsial berpengaruh terhadap perkembangan usaha UMKM di Kabupaten Banyumas.

3. Kualitas Sumber daya manusia adalah variabel yang paling berpengaruh terhadap perkembangan usaha UMKM di Kabupaten Banyumas. 


\section{DAFTAR PUSTAKA}

Agoes, Sukrisno. 2007. Auditing (pemeriksaan Akuntan) oleh Akuntan Publik. Julid 1: Edisi Ketiga, Lembaga Penerbit Fakultas Ekonomi Universitas Indonesia: Jakarta

Anonimous. 2000. perkembangan usaha koperasi simpan pinjam tahun 1996 - tahun 2000. Balitbangkop dan PKM, Departemen Koperasi, Pengusaha Kecil dan Menengah, Jakarta.

Anonimous. 1992. Undang-Undang Nomor 25 Tahun 1992 tentang Perkoperasian

Antara, Made \& Anderson Guntur Komenaung. 2004. Kinerja Koperasi Unit Desa di Propinsi Bali: Pendekatan Structural Equation Model. Diakses melalui www.google.com pada tanggal 16 November 2011

Boynton, William C., et al. 2001. Modern Auditing. Jilid 1. Edisi ketujuh. Diterjemahkan olehDrs. Paul A. Rajoe. Penerbit Erlangga: Jakarta

Daeli, Atozisochi Daeli, Amru Nasution \& Matias Slagian. 2006. Pengaruh kualitas sumber daya manusia pengelola koperasi terhadap perkembangan koperasi unit desa kabupaten Nias. Jurnal Studi Pembangunan. April 2006 volume 1 no. 2

Dinas Tenaga kerja, Koperasi dan UMKM Kabupaten Banyumas. 2015. Data UMKM Propinsi Jawa Tengah Kabupaten Banyumas

Ghozali, Imam. 2006. Aplikasi Analisis Multivariate Dengan Program SPSS. Badan Penerbit Universitas Diponegoro: Semarang

Ghozali, Imam. 2009. Ekonometrika Teori, Konsep dan Aplikasi
Dengan SPSS17. Badan Penerbit Universitas Diponegoro: Semarang

Handoko, T. Hani. 2003. Manajemen. Cetakan Kedelapanbelas. Penerbit BPFE: Yogyakarta

Izzaty, Khairina Nur. 2011. Pengaruh Gaya Kepemimpinan dan Kualitas Sumber Daya Manusia terhadap Penerapan Anggaran Berbasis Kinerja

Badan Layanan Umum. Skripsi. Universitas Diponegoro. Semarang. Diakses melalui www.google.com. Pada tanggal 20 November 2011

Keputusan Menteri Negara Koperasi dan Usaha Kecil Menengah Nomor $96 \quad$.2004. Tentang Pedoman Standar Operasional Manajemen Koperasi

Simpan Pinjam dan Unit Simpan Pinjam Koperasi

Mulyadi. 2001. Sistem Informasi Akuntansi. Salemba Empat: Jakarta

Ompusunggu, Halomoan. 2002. Pengaruh Penerapan Sistem Informasi Akuntansi Terhadap Efektivitas Pelaksanaan Sistem Pengendalian Intern. Jurnal Ilmiah Akuntansi Vol.1 No.2

Patriatiningrum, Rakhmawati. 2007. Analisis Penerapan PSAK No. 27 dan Pengeruhnya Terhadap Perkembangan Usaha Pada KUD di Kabupaten Kendal Tahun 2004-2005. Skripsi. Universitas Negeri Semarang

Peraturan Menteri Negara Koperasi dan Usaha Kecil Menengah Nomor 15. 2009.Tentang Perubahan Atas Peraturan Menteri Negara dan Usaha Kecil Menengah Nomor 19/Per/M.KUKM/XI/2008

Tentang Pedoman Pelaksanaan 
Kegiatan Usaha Simpan Pinjam Oleh Koperasi

Pratolo, Suryo. 2007. Good Corporate Governance dan Kinerja BUMN di Indonesia: Aspek Audit Manajemen dan Pengendalian Intern Sebagai Variabel Eksogen Serta Tinjauannya Pada Jenis Perusahaan. Simposium Nasional Akuntansi X. UNHAS MakasarRachmat, Sanyoto. 2006. Analisis Kondisi Lingkungan Pengendalian dalam Sistem Pengendalian Intern Bank BTN. Tesis. Program Pasca Sarjana Universitas Diponegoro. Semarang

Rantau, Ketut. 1993. Pengaruh Partisipasi, Anggota, Kualitas Pengelola, Kualitas Pengurus dan Peranan Pemerintah Terhadap Keberhasilan Usaha
Koperasi. Penelitian. Diakses melalui www.google.com pada tanggal 31 Januari 2012

Soedirman. 2006. Koperasi Indo. Diakses melalui www.edukasi.com. Pada tanggal 1 November 2011

Sulaeman, Suhendar. 2002. Eksistensi Koperasi Simpan Pinjam. Penelitian. Diakses melalui www.gooogle.com pada tanggal 1 November 2011

Suliyanto. 2011. Ekonometrika Terapan Teori dan Aolikasi Dengan SPSS.Penerbit Andi: Yogyakarta

Wiryo, Wiloejo. 2005. Pemberdayaan Lembaga Keuangan Mikro Sebagai Salah Satu Pilar Sistem Keuangan Nasional. Kajian ekonomi dan keuangan. 